\title{
Glioblastoma cells express functional cell membrane receptors activated by daily used medical drugs
}

\author{
Susanne A. Kuhn · Ulrike Mueller • Uwe-K. Hanisch • Christian R. A. Regenbrecht • \\ Ilona Schoenwald • Michael Brodhun · Hartwig Kosmehl • \\ Christian Ewald $\cdot$ Rolf Kalff $\cdot$ Rupert Reichart
}

Received: 26 February 2009 / Accepted: 2 June 2009 / Published online: 19 June 2009

(C) Springer-Verlag 2009

\begin{abstract}
Purpose Calcium ions are highly versatile spacial and temporal intracellular signals of non-excitable cells and have an important impact on nearly every aspect of cellular life controlling cell growth, metabolism, fluid secretion, information processing, transcription, apoptosis, and motility. Neurons and glia respond to stimuli, including neurotransmitters, neuromodulators, and hormones, which increase the intracellular calcium concentration. The function of intracellular calcium in gliomas is unknown. Lots of daily used drugs may act via receptors that can be linked to the intracellular calcium system and therefore could influence glioma biology.

Methods Glioma cells were loaded with the calcium ion sensitive dye Fura 2-AM. Subsequently, cells were stimulated with 25 different medical drugs for $30 \mathrm{~s}$. The increase
\end{abstract}

S. A. Kuhn $(\bowtie) \cdot$ I. Schoenwald · C. Ewald · R. Kalff · R. Reichart Department of Neurosurgery, Medical Center,

Friedrich-Schiller-University, Erlanger Allee 101,

07747 Jena, Germany

e-mail: Susanne.Kuhn@med.uni-jena.de

S. A. Kuhn · U. Mueller

SKP Services, Dresden, Germany

Uwe-K. Hanisch

Institute of Neuropathology, Medical Center,

Georg-August-University, Goettingen, Germany

C. R. A. Regenbrecht

Max-Planck-Institute of Molecular Genetics, Berlin, Germany

M. Brodhun · H. Kosmehl

Institute of Pathology, Helios Hospital, Erfurt, Germany of free intracellular calcium ions was measured and calculated by a microscope-camera-computer-unit.

Results Except for the buffer solution HEPES that served as negative control and for the cortisol derivative dexamethasone, all other 24 tested drugs induced a rise of intracellular calcium ions. The cellular calcium responses were classified into seven functional groups. The tested substances activated several types of calcium channels and receptors.

Conclusions Our study impressively demonstrates that medical drugs are potent inducers of intracellular calcium signals. Totally unexpected, the results show a high amount of functional cellular receptors and channels on glioma cells, which could be responsible for certain biological effects like migration and cell growth. This calcium imaging study proves the usability of the calcium imaging as a screening system for functional receptors on human glioma cells.

Keywords Glioma $\cdot$ Calcium imaging · Drugs · Cell-surface receptors $\cdot$ Tumor proliferation .

Tumor invasion

\section{Introduction}

Mammalian glial cells express a broad spectrum of neuroligand receptors and ion channels as do neurons and other excitable cells as well (Baimbridge et al. 1992; Bender and Hertz 1987; Bernstein et al. 1996; Bordey et al. 1994; Castillo et al. 2007; Fatatis et al. 1994; Albrecht et al. 2001; Friel 1995; Han et al. 2002; Hösli and Hösli 1987; Hösli et al. 1984; Kirischuk et al. 1996; Möller 2002; Nielsen et al. 1990; Sharma et al. 2001; Verkhratsky et al. 1998; Färber and Kettenmann 2006; Verkhratsky and Shmigol 
1996; Weydt et al. 1997; Wienrich and Kettenmann 1989; Perea and Araque 2005). These receptors are known on glial cells as adenosine triphosphate, acetylcholine, bradykinin, endothelin, $\gamma$-aminobutyric acid, glycine, glutamate, histamine, oxytocin, platelet-activating factor, substance $\mathrm{P}$, and many other receptors (Verkhratsky et al. 1998; Wienrich and Kettenmann 1989; Verkhtatsky and Steinhäuser 2000). New results show astrocytic calcium signaling to play a pivotal role in the astrocyte-neuron interaction and in the regulation of local cerebral blood supply in dependence of neuronal activity (Perea and Araque 2005; Schipke et al. 2002; Peters et al. 2003; Lovick et al. 2005; Gordon et al. 2008; Anderson and Nedergaard 2003; Iadecola and Nedergaard 2007; Straub and Nelson 2007).

However, very little data exists about the expression and the functional role of neuroligand receptors and ion channels in human glioma cells (Weydt et al. 1997; Sontheimer 2003, 2004, 2008a, b; Lyons et al. 2007; McCoy and Sontheimer 2007; Weaver et al. 2006; Olsen et al. 2003; Synowitz et al. 2001; Labrakakis et al. 1998a, b). Only a few publications confirm an impact of neuroligand receptors and ion channels for glioma proliferation and migration (Sharma et al. 2001; Sontheimer 2003, 2004, 2008a, b; Lyons et al. 2007; McCoy and Sontheimer 2007; Weaver et al. 2006; Olsen et al. 2003; Synowitz et al. 2001).

Calcium ions are known to play an important role in the regulation of cellular processes, like the regulation of gene expression, cellular migration, metabolism, and proliferation (Perea and Araque 2005; Berridge 2008; Berridge et al. 2003; Clapham 2007; Jaiswal 2001; Parekh 2006; Parekh and Penner 1997; Berridge et al. 2003). As a prerequisite, the concentration of free intracellular calcium ions $\left[\mathrm{Ca}^{2+}\right]_{\mathrm{i}}$ in the cytosol needs to be permanently constant with less than $10^{-5} \mathrm{M}$ (Verkhratsky et al. 1998; Verkhtatsky and Steinhäuser 2000). Most of the free intracellular calcium ions are stored, for instance, in the sarcoplasmic and endoplasmic reticulum or bound to calcium binding proteins like calbindin, calmodulin, and calsequestrin (Berridge et al. 2003). After the stimulation of the cells, their intracellular free calcium ions may rise to the tenfold of the basal level, which activates a multitude of cellular reactions via the so called calcium signaling (Verkhtatsky and Steinhäuser 2000; Berridge et al. 2003; Parekh 2008; Barres 2008; Iino 2008).

Calcium signals are caused by the interaction of several mechanisms like the influx of calcium ions through the cellular membrane into the cell caused by an electrochemical gradient. In addition to that, calcium ions can be released from intracellular stores into the cytoplasm (Verkhtatsky and Steinhäuser 2000; Parekh 2008; Blaustein and Golovina 2001). A calcium outflow into the extracellular compartment and into the intracellular stores lowers the increased intracellular calcium ion concentration and enables the maintenance of the low basal level.
The influx of calcium ions into the cytoplasm across the cell membrane involves calcium permeable ion channels. The cellular membrane contains voltage-gated calcium channels (VGCC) that open, when action potentials are generated and cause a depolarization of the cellular membrane, receptor-operated calcium channels (ROCs) which are regulated by ligand binding, and store-operated calcium channels (SOCs) that are activated by a calcium release from intracellular stores like the endo- or sarcoplasmic reticulum (Verkhtatsky and Steinhäuser 2000; Blaustein and Golovina 2001). The store-operated calcium channels cause an influx of calcium ions from the cytoplasm into the empty intracellular stores. The calcium ion release from intracellular stores is mainly regulated by the second messenger inositol-1,4,5-trisphosphate (IP3)-sensitive calcium channels (Verkhratsky et al. 1998; Verkhtatsky and Steinhäuser 2000; Berridge 2008; Parekh 2006; Parekh and Penner 1997; Blaustein and Golovina 2001; Putney 2007; Putney 1997). IP3 is produced after the stimulation of G-protein coupled neuroligand

Fig. 1 Prerequisites of calcium imaging $(a-e)$ and types of cellular calcium responses $(f-j)$. a Chemical structure of the calcium ion sensitive compound Fura-2 AM in its ester version. After diffusion of Fura-2 AM into the cell, esterases cleave the esther bond and prevent the Fura's diffusion out of the cell. b Fundamental equation for the evaluation of the ratio of the frequencies at wavelengths of 340 and $380 \mathrm{~nm}$. c Photography of a calcium imaging set up with the microscope-camera-computer-unit. d The calcium-sensitive dye Fura-2 changes its excitation wavelength upon the binding of calcium ions. The more calcium ions are within the cytoplasm, the more calcium ions are bound by Fura-2. The shift of the wavelength is recognized by the camera and saved by the computer. The higher the intracellular calcium concentration is, the more shifts the color of the cells to green, yellow, or red. e Regions of interest (ROIs) can be defined in distinct cells. The color shift is calculated by the computer and translated into a ration curve in dependence on the time. $\mathbf{f}-\mathbf{j}$ Distinct types of intracellular calcium responses without intermediate states (modified from Möller (2002)). f This type of calcium signal is characterized by its transient nature with a fast initial rise and a rapid falling component. Opening of intracellular stores and/or transiently open cell membrane channels cause an influx of free calcium ions into the cell. Free calcium ions subsequently are cleared from the cytoplasm. ATP-dependent $\mathrm{Ca}^{2+}$ pumps transport the calcium ions into the intracellular stores and into the extracellular compartment. Calcium signals that resemble this course are considered type 1 in our study. $\mathbf{g}$ This type of transient calcium signal is caused by and initial maximum calcium concentration followed by a plateau. The signal results from an initial influx of calcium ions from intracellular stores and/or from the extracellular compartment via cell membrane channels. This is followed by a slower calcium influx via receptor-operated calcium channels or storeoperated calcium channels. Free calcium ions are cleared thereafter from the cytoplasm by ATP-dependent calcium pumps to maintain the non-toxic basal level. Calcium responses that resemble this signal are considered type 2 . $\mathbf{h}$ This type of calcium signal is characterized by repeated oscillations that are caused by a complex interaction between calcium release from intracellular stores and calcium influx through open store-operated channels. Calcium responses of this form are considered type 3. j A slowly rising intracellular calcium ion level is mostly caused by a very slowly increasing calcium conductibility of the cellular membrane or a modulation of calcium extrusion mechanisms. Signals that are similar to this course are summarized as type 4 

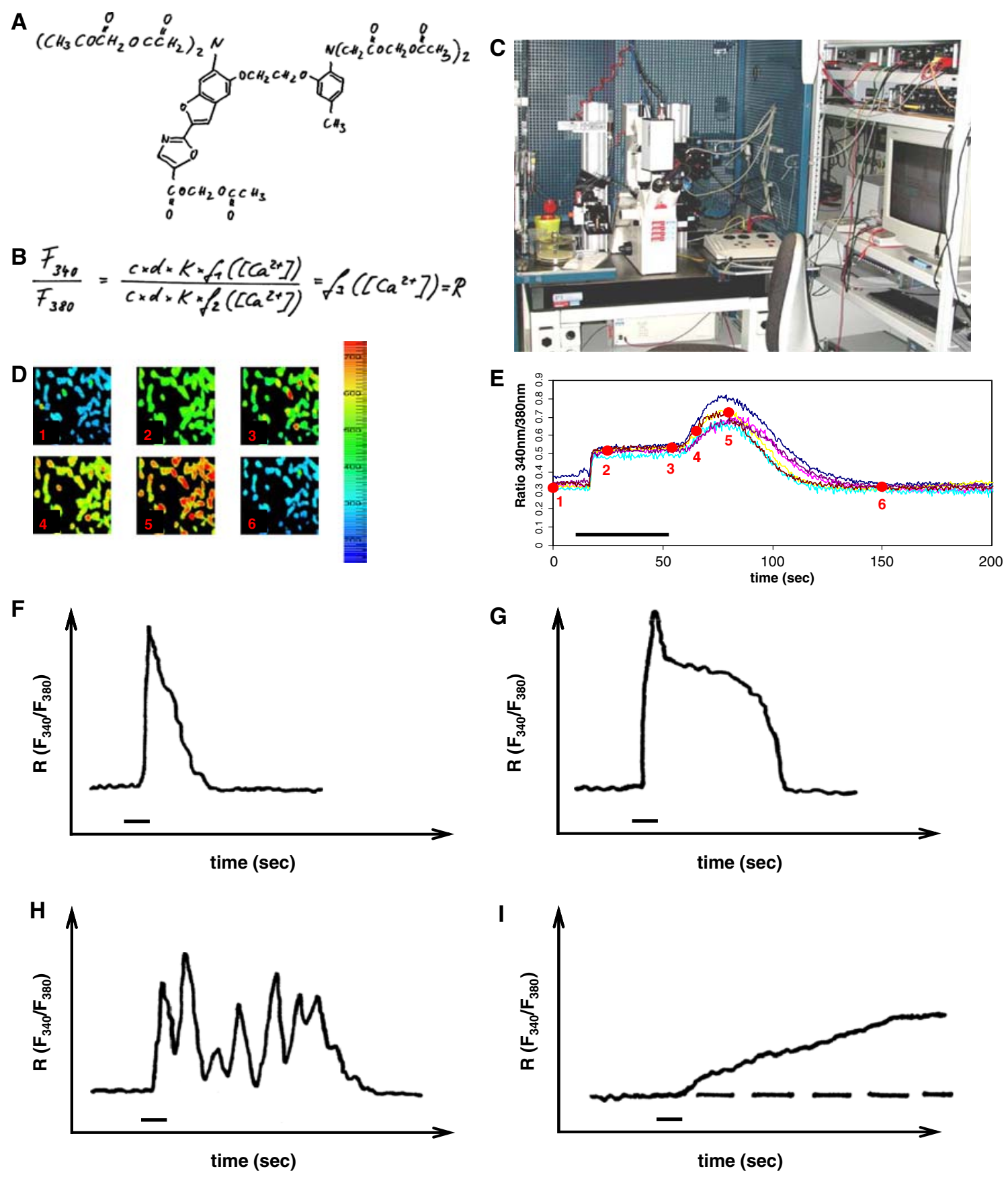

receptors after activation of phospholipase $\mathrm{C}$ via trimere G-proteins (Verkhratsky et al. 1998; Verkhtatsky and Steinhäuser 2000; Berridge 2008; Parekh 2006; Parekh and Penner 1997; Blaustein and Golovina 2001; Putney 2007; Putney 1997). The opening of IP3 sensitive calcium channels may be strengened by cytoplasmic calcium ions, thereby causing a further induction of calcium release. This phenomenon is called calcium induced calcium release (CICR) (Verkhratsky et al. 1998; Verkhtatsky and Steinhäuser 2000; Berridge 2008; Parekh 2006; Parekh and Penner 1997; Blaustein and Golovina 2001; Putney 2007; Putney 1997).

Additionally, the activation of ryanodine receptors may increase the calcium release from intracellular stores into the cytoplasm. (Berridge et al. 2003; Blaustein and Golovina 2001; Matyash et al. 2002; Bardo et al. 2006). Neurons and astrocytes express ryanodine receptors (Matyash et al. 2002; Bardo et al. 2006). Whether glioma cells carry ryanodine receptors is not yet known. Adenosine triphosphat activated calcium pumps $\left(\mathrm{Ca}^{2+}\right.$-ATPases $)$ in the cellular membrane and in the membranes of intracellular calcium stores transfer free calcium ions, which are toxic for the cell, out of the cytoplasm into the extracellular 
Table 1 Summary of all tested 26 substances including their used dosage and their producing companies

\begin{tabular}{|c|c|c|c|c|}
\hline \multirow{2}{*}{$\begin{array}{l}\text { Medical preparation } \\
\text { (1) Histamine }\end{array}$} & \multirow{2}{*}{$\begin{array}{l}\text { Dosage/amount } \\
100 \mu \mathrm{M}\end{array}$} & \multicolumn{3}{|l|}{ Purchased from } \\
\hline & & Sigma Aldrich & Taufkirchen & Germany \\
\hline (2) Substance P & $100 \mu \mathrm{M}$ & Sigma Aldrich & Taufkirchen & Germany \\
\hline (3) Vasoactive intestinal polypeptide & $100 \mu \mathrm{M}$ & Sigma Aldrich & Taufkirchen & Germany \\
\hline (4) Neurokinin A & $100 \mu \mathrm{M}, 10 \mu \mathrm{M}$ & Sigma Aldrich & Taufkirchen & Germany \\
\hline (5) Neurokinin B & $10 \mu \mathrm{M}$ & Sigma Aldrich & Taufkirchen & Germany \\
\hline (6) Potassium ions & $1 \mathrm{M}$ & Fresenius SE & Bad Homburg & Germany \\
\hline (7) Calcium ions & $1 \mathrm{M}$ & Sandoz Pharmaceuticals GmbH & Holzkirchen & Germany \\
\hline (8) Sodium ions & $1 \mathrm{M}$ & Fresenius SE & Bad Homburg & Germany \\
\hline (9) Dexamethasone & $4 \mathrm{mg}$ & Merck KGaA & Darmstadt & Germany \\
\hline (10) Clonidine & $0.15 \mathrm{mg}$ & AWD.pharma GmbH \& Co. KG & Radebeul & Germany \\
\hline (11) Theophylline & $20 \mathrm{mg}$ & Altana Pharma Deutschland GmbH & Konstanz & Germany \\
\hline (12) Droperidol & $1.25 \mathrm{mg}$ & Janssen Pharmaceutica & Beerse & Belgium \\
\hline (13) Metamizol & $50 \mathrm{mg}$ & Rationpharm GmbH & Ulm & Germany \\
\hline (14) Cafedrin/theodrenalin (combi) & $100 \mathrm{mg} / 5 \mathrm{mg}$ (combi) & AWD.pharma GmbH \& Co. KG & Radebeul & Germany \\
\hline (15) Promethazine & $25 \mathrm{mg}$ & Bayer Vital GmbH & Leverkusen & Germany \\
\hline (16) Diazepam & $5 \mathrm{mg}$ & Rationpharm GmbH & Ulm & Germany \\
\hline (17) Hydrocortisone & $5 \mathrm{mg}$ & Teopharma & Valle Salimbene & Italy \\
\hline (18) Thiamazole & $4 \mathrm{mg}$ & Temmler Pharma GmbH \& Co. KG & Marburg & Germany \\
\hline (19) Physostigmin & $0.4 \mathrm{mg}$ & Dr. F. Köhler Chemie & Alsbach-Hähnlein & Germany \\
\hline (20) Haloperidol & $5 \mathrm{mg}$ & Rationpharm GmbH & Ulm & Germany \\
\hline (21) Phenytoin & $10 \mathrm{mg}$ & Desitin Arzneimittel GmbH & Hamburg & Germany \\
\hline (22) Epinephrine & $1 \mathrm{mg}$ & Jenapharm GmbH \& Co. KG & Jena & Germany \\
\hline (23) Urapidil & $5 \mathrm{mg}$ & Altana Pharma Deutschland GmbH & Konstanz & Germany \\
\hline (24) Metoclopramide & $5 \mathrm{mg}$ & Hexal AG & Holzkirchen & Germany \\
\hline (25) Dimetindene & $1 \mathrm{mg}$ & Novartis Consumer Health $\mathrm{GmbH}$ & München & Germany \\
\hline (26) HEPES buffer & Components see text & Sigma Aldrich & Taufkirchen & Germany \\
\hline
\end{tabular}

compartment or into the endo- or sarcoplasmic reticulum against the electrochemical gradient.

All these mechanisms regulate the important ion calcium. The expression of receptors and ion channels linked to intracellular calcium ion signaling have been shown for all types of glial cells in vitro as well as in situ and for different groups of neurons. The amplitude and kinetics of a calcium ion signal is determined by pharmacological features of the neuroligand receptor, the ion channel, and the parameters of its cytosolic calcium effector cascade. The release of calcium ions from inositol-1,4,5-triphopshate or ryanodine-sensitive intracellular calcium stores, the status of calcium release-activated calcium channels, and the efficacy of the calcium-buffering systems are significant terminators of the calcium response.

In the present study, human glioma cells were tested for their ability to raise the intracellular free calcium ion concentration upon stimulation of neuroligand receptors or ion channels via daily used medical drugs. Calcium imaging was used as a screening method to detect receptor mechanisms that could influence glioma biology significantly.

\section{Materials and methods}

Cell culture

Human glioma cell lines U373MG and U87MG were cultured for 5-10 days in Dulbecco's Modified Eagle Medium (DMEM) with the supplement of $10 \%$ fetal calf serum (FCS) at a temperature of $37^{\circ} \mathrm{C}, 5 \%$ carbon dioxide, $95 \%$ oxygen, and $95 \%$ humidity. Prior to measurements, cells were seeded on glass coverslips at a density of $1 \times 10^{4}$ cells and allowed to adapt for $24 \mathrm{~h}$.

Calcium measurements via "Calcium Imaging"

All experiments were performed at least in triplicate under permanent perfusion with HEPES buffer made from $\mathrm{NaCl}$ (150 mM), $\mathrm{KCl}$ (5.4 mM), $\mathrm{CaCl}_{2}$ (2 mM), $\mathrm{MgCl}_{2}$ (1 mM), HEPES/NaOH $(10 \mathrm{mM})$, and glucose $(10 \mathrm{mM})$ at a $\mathrm{pH}$ of 7.35 at room temperature.

The "Calcium Imaging" is an imaging procedure, which measures the concentration of free intracellular calcium 
Table 2 Groups of drugs are correlated to their appropriate type of elicited calcium signal

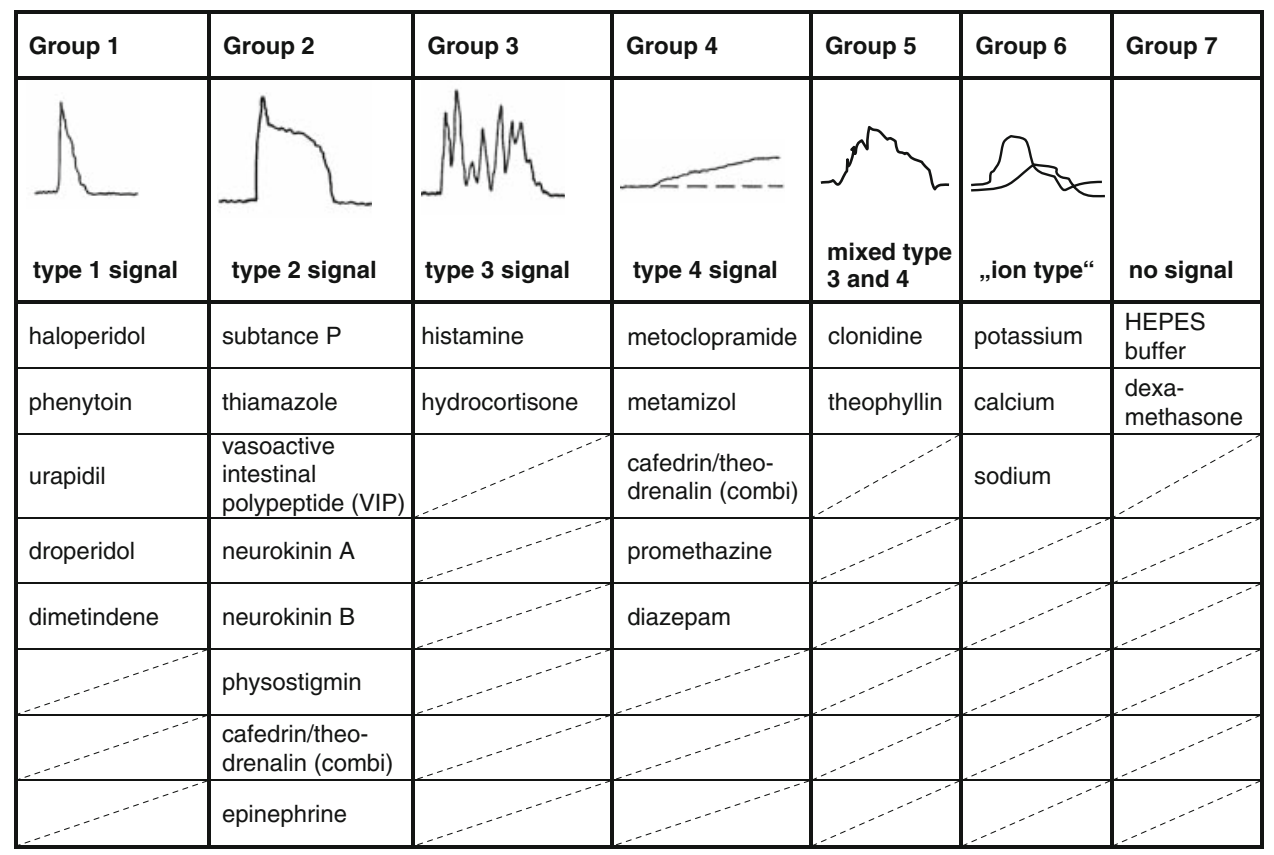

Sketches of calcium signals are used to illustrate the groups according to the sketches in Fig. 1. All substances of every group eliciting their specific calcium response are listed. The combined drug made from cafedrin and theodrenalin is sorted into group 2 and group 4 according to the shape of the calcium response and according to the supposed calcium signals elicited by both substances in single preparations

ions $\left(\left[\mathrm{Ca}^{2+}\right]_{\mathrm{i}}\right)$ or their dynamic changes by fluometry. $\left[\mathrm{Ca}^{2+}\right]_{\mathrm{i}}$ was monitored using the calcium-sensitive fluorescent indicator fura-2 acetoxy methyl ester (fura-2 AM) from Molecular Probes (Eugene, Oregon, USA). Fura-2 AM permeates through the cellular membrane and looses its ester bond by hydrolysis, which causes the generation of its acidic form (Fig. 1). This acid (fura-2) does not diffuse out of the cell and specifically binds free calcium ions. By binding calcium ions, fura- 2 changes its specific wave length and frequency. This change can be measured and calculated (Fig. 1). Cells were loaded with fura-2 AM ( $5 \mu \mathrm{M}$; stock solution in DMSO) by incubation in bathing solution for $30 \mathrm{~min}$ at $37^{\circ} \mathrm{C}$ within the incubator. Subsequently, cells were superfused with HEPES buffer, and images were taken every $3 \mathrm{~s}$. After $15 \mathrm{~s}$, cells were stimulated with 25 different drugs for $30 \mathrm{~s}$ and the HEPES buffer solution as a negative control (Table 1). For fura-2 excitation, cells were illuminated at two alternating wavelengths, $340 \pm 5$ and $380 \pm 5 \mathrm{~nm}$, respectively (Fig. 1). Excitation was performed by a monochromator (Polychrome IV; T.I.L.L. Photonics, Martinsried, Germany). The emitted light was collected at $530 \pm 10 \mathrm{~nm}$ by the long-term exposure CCD camera QuantiCam Long Exposure VGA-b/w (Phase, Luebeck, Germany) coupled to a Zeiss Axioskop (Oberkochen, Germany) equipped with a $20 \times$ water immersion Zeiss objective with a numerical aperture of 0.5 (Fig. 1). The monochromator and CCD camera were controlled by TILL Photonics software TILLvisION (TILL
Photonics, Graefelfing, Germany), being also used for image processing. Data analysis was performed after the definition of a region of interest (ROI) with standard personal computer software. The $\left[\mathrm{Ca}^{2+}\right]_{\mathrm{i}}$ was calculated from the ratio (R) of fluorescence recorded at 340 and $380 \mathrm{~nm}$ excitation wavelengths (Fig. 1). In all experiments, the basal calcium level within the cytoplasm before the stimulation with the 25 different substances was measured at the ratio $(R=\mathrm{F} 340 / 380)$ between 0.3 and 0.5 that was in concordance with a typical ratio for viable resting cells (Fig. 1). According to the shape of the resulting transient calcium signal, cellular responses were classified into distinct types (Fig. 1).

\section{Results}

Classification of intracellular calcium responses into seven types

According to our knowledge about the shape and course of transient intracellular calcium ion increases, we classified the reaction of our cells to the substituted medical drugs into seven types (Table 2) (Möller 2002). The calcium signals of the groups 1-4 are called signals of the types 1-4. Group 5 consists of medical drugs that caused calcium raises, similar to a mixed type 3 and 4 . Group 6 consists of ion preparations; the according calcium signals are called 
Fig. 2 Substances of group 1 that elicit type 1 calcium signals. The table indicates the positive cells out of all tested cells for every medical drug. The numbers in brackets indicate the positively tested cells in every single experiment. a-c The graphics below depict the courses of the calcium signals after administration of phenytoin, dimetindene, and droperidol to the human glioma cells in typical experimental settings. The bars indicate the duration of substance administration according to the details mentioned in "Methods"

\begin{tabular}{|l|l|l|}
\hline Substances of group $\mathbf{1}$ & $\begin{array}{l}\text { Positive calcium } \\
\text { signal in U87MG cells }\end{array}$ & $\begin{array}{l}\text { Positive calcium } \\
\text { signal in U373MG cells }\end{array}$ \\
\hline Haloperidol & $67 / 68$ cells $(24+19+25)$ & $19 / 23$ cells $(10+7+6)$ \\
\hline Phenytoin & $21 / 21$ cells $(8+4+9)$ & $11 / 19$ cells $(4+6+9)$ \\
\hline Urapidil & $30 / 32$ cells $(15+7+10)$ & not tested \\
\hline Droperidol & $39 / 39$ cells $(13+12+14)$ & not tested \\
\hline Dimetindene & $25 / 29$ cells $(14+8+7)$ & not tested \\
\hline
\end{tabular}
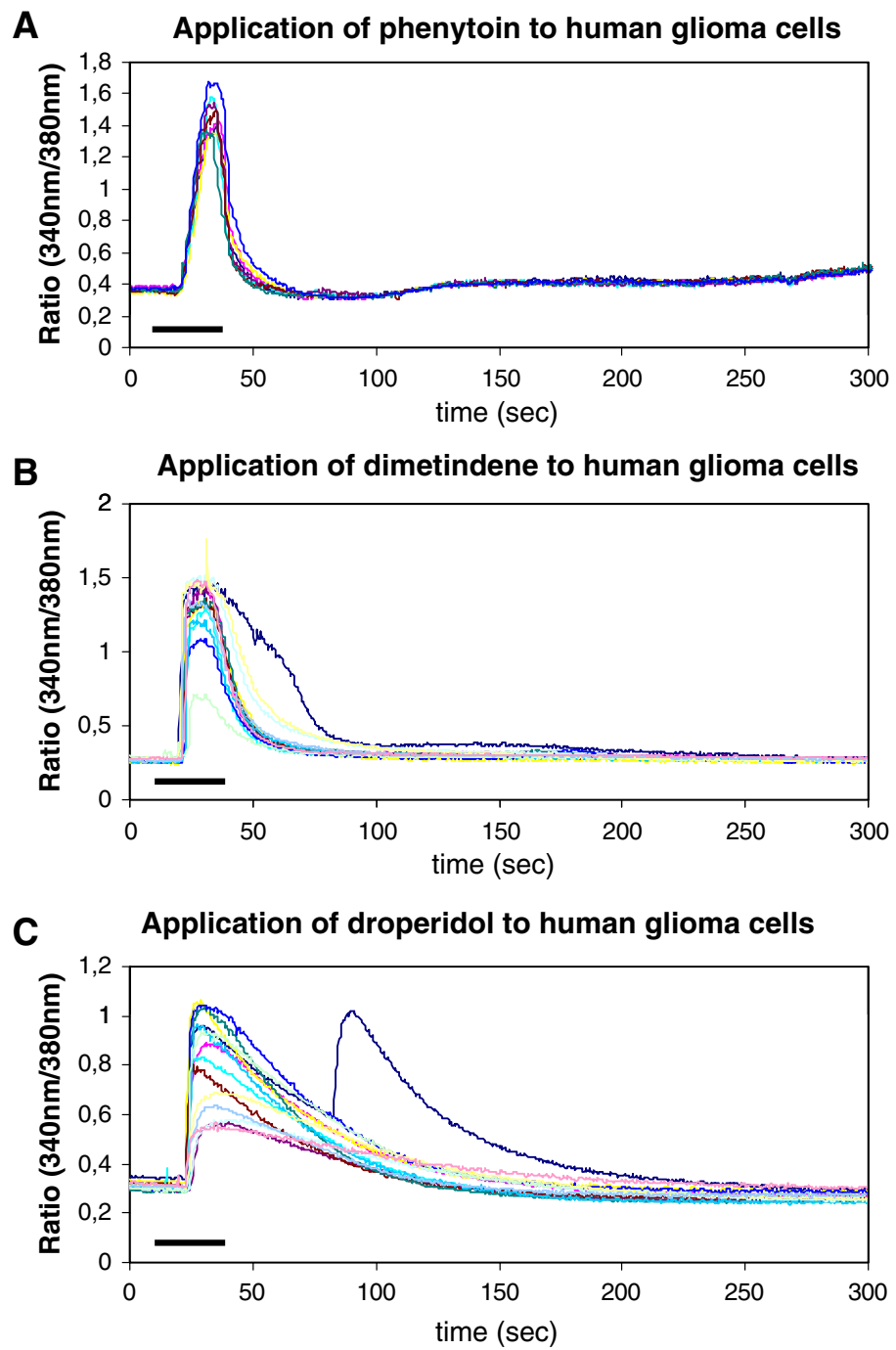

"ion type" signals. The only substances those did not elicit a calcium response are summarized into group 7 .

\section{Calcium signals of type 1}

Group 1 was formed by substances that established a fast initial increase of free intracellular calcium ions with a rapid falling component. The opening of intracellular stores and/or transiently open cell membrane channels can cause an influx of free calcium ions that resembles the trace in
Fig. 1f (Möller 2002). Calcium responses that resemble this course are considered type 1 in our study. The included substances are: haloperidol, urapidil, droperidol, dimetindene, and phenytoin, (Table 2, Figs. 1, 2).

Haloperidol, urapidil, dimetindene, droperidol, and phenytoin caused intracellular calcium signals to raise and fall quickly and sharply. In summary, 182 cells of all 189 tested U87MG glioblastoma cells and 30 of the 42 tested U373MG cells showed the type 1 calcium response (Fig. 2). 
Fig. 3 Substances of group 2 that induce type 2 calcium signals with a typical "calcium shoulder" are illustrated. The table indicates the positive cells from all tested cells. a-c The graphics below show the calcium responses from typical experiments upon the stimulation with neurokinin A, neurokinin $\mathrm{B}$, and substance $\mathrm{P}$. The bars indicate the duration of substance administration according to the details mentioned in "Methods"

\begin{tabular}{|l|l|l|}
\hline Substances of group 2 & $\begin{array}{l}\text { Positive calcium signal in } \\
\text { U87MG cells }\end{array}$ & $\begin{array}{l}\text { Positive calcium signal in } \\
\text { U373MG cells }\end{array}$ \\
\hline Substance P & $70 / 81$ cells $(30+33+18)$ & $63 / 63$ cells $(29+22+12)$ \\
\hline VIP & $61 / 61$ cells $(15+22+24)$ & $21 / 21$ cells $(6+9+6)$ \\
\hline Neurokinin A & $42 / 42$ cells $(12+14+16)$ & $90 / 95$ cells $(31+29+33)$ \\
\hline Neurokinin B & $43 / 45$ cells $(19+9+7+10)$ & $52 / 55$ cells $(19+22+14)$ \\
\hline Thiamazole & $31 / 31$ cells $(7+15+9)$ & not tested \\
\hline Physostigmin & $32 / 35$ cells $(13+9+13)$ & $10 / 11$ cells $(3+4+4)$ \\
\hline Epinephrine & $30 / 30$ cells $(19+6+15)$ & not tested \\
\hline Cafedrin/Theodrenalin (combi) & $41 / 41$ cells $(14+14+13)$ & not tested \\
\hline
\end{tabular}
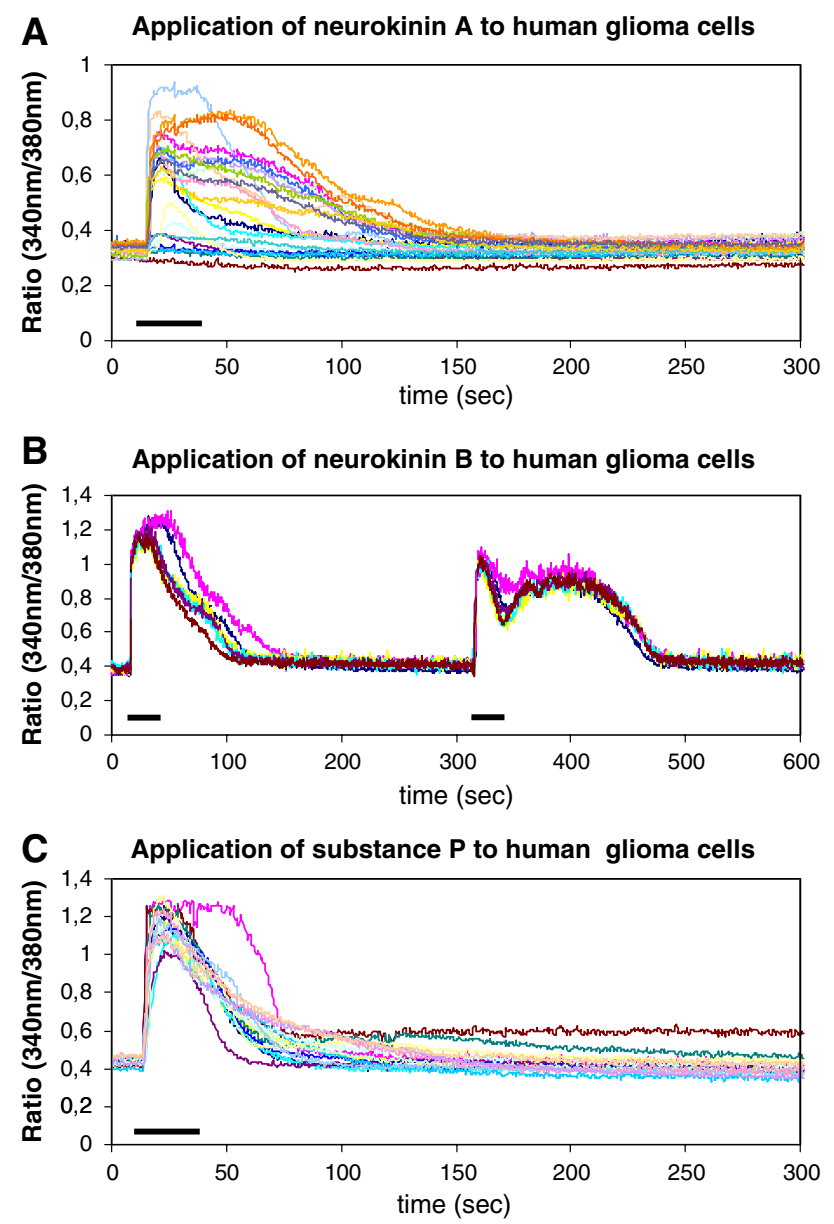

Calcium signals of type 2

Group 2 was formed by the medical drugs that, when applied, resulted in a transient calcium signal with a slow initial maximum followed by a plateau phase. The calcium answer represents a mixed type of calcium ion increase within the cytoplasm. This results from an initial influx of calcium ions from intracellular stores and/or from the extracellular compartment. This is then followed by a calcium flow via receptor operated calcium channels or store operated calcium channels (Möller 2002). This group consists of substance $\mathrm{P}$, vasoactive intestinal polypeptide, neurokinin A, neurokinin B, physostigmine, epinephrine, and thiamazole. The combination from cafedrine and theodrenalin causes a mixed calcium ion signal composed of type 2 and type 4 of calcium signals (Table 2, Figs. 1, 3).

Substance $P$, vasoactive intestinal polypeptide, neurokinin $\mathrm{A}$, neurokinin $\mathrm{B}$, thiamazole, physostigmin, and epinephrine were administered to the cultured human glioblastoma cells. The calcium response is characterized 
Fig. 4 The drugs of group 3 elicit typical type 3 calcium signals with the characteristic calcium oscillations. Histamine and hydrocortisone belong to this group of substances. a-c The graphics below show the calcium oscillations upon the single of twofold administration of histamine and hydrocortisone, respectively. The bars indicate the duration of substance administration according to the details mentioned in "Methods"

\begin{tabular}{|l|l|l|}
\hline Substances of group 3 & $\begin{array}{l}\text { Positive calcium signal in } \\
\text { U87MG cells }\end{array}$ & $\begin{array}{l}\text { Positive calcium signal in } \\
\text { U373MG cells }\end{array}$ \\
\hline Histamine & $78 / 78$ cells $(30+15+19+14)$ & $51 / 51$ cells $(4+15+12+7+13)$ \\
\hline Hydrocortisone & $56 / 56$ cells $(23+15+18)$ & $16 / 16$ cells $(8+4+4)$ \\
\hline
\end{tabular}
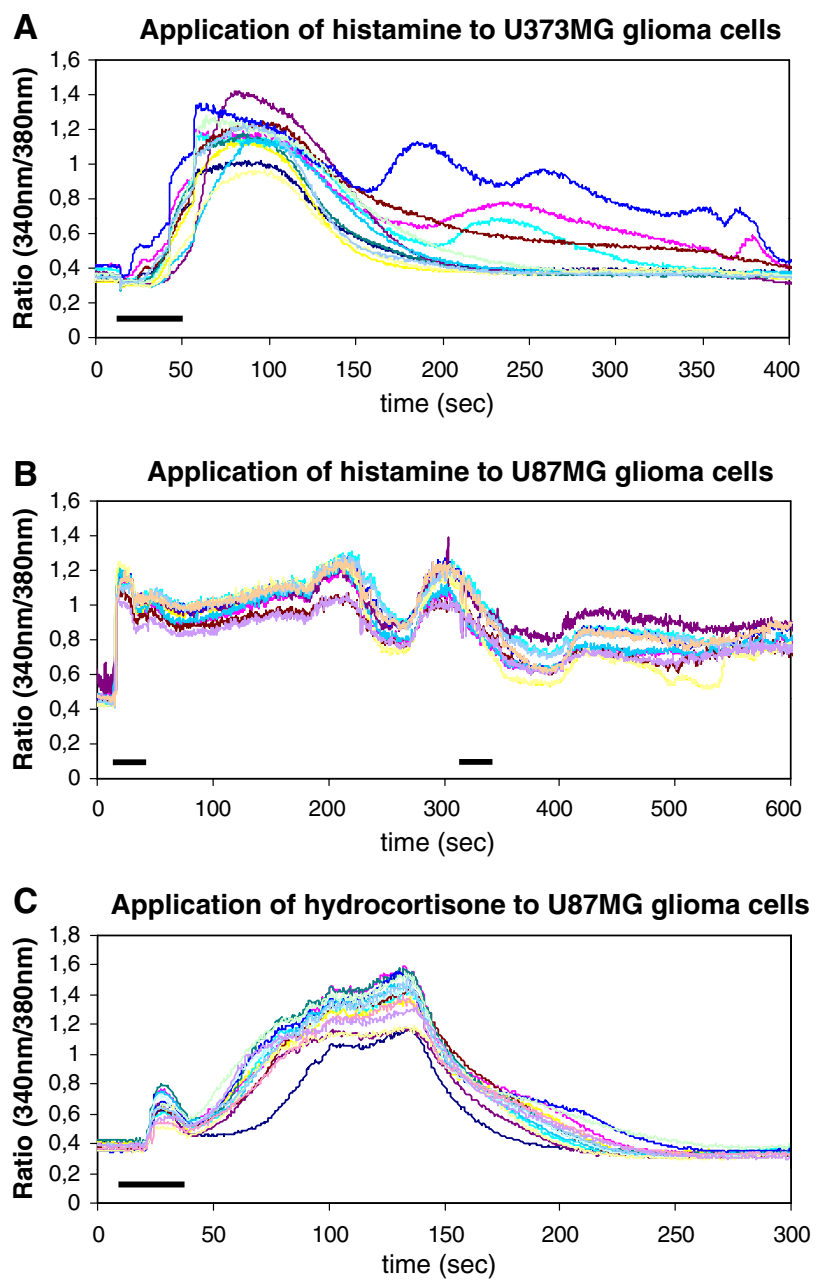

by the typical fast rise of the intracellular free calcium ions being followed by a long-lasting plateau phase, also called "calcium shoulder". After this plateau, the intracellular concentration of free calcium ions slowly returned to the cellular basal calcium level (Fig. 3). Three hundred and seventy-nine cells of the U373MG cells $(n=403)$ and 268 cells of the U87MG cells $(n=277)$ showed a postive calcium response upon exposure of the different substances (Fig. 3).

\section{Calcium signals of type 3}

Group 3 consists of substances that cause intracellular calcium oscillations. These calcium oscillations result from a complex interaction between calcium influx mechanisms, via calcium release from internal stores or open store operated calcium channels, and calcium outflux processes, which refill the intracellular stores and transport calcium ions into the extracellular milieu (Möller 2002). Histamine and hydrocortisone caused this type of calcium signal in our glioblastoma cells (Table 2, Fig. 1, 4).

The stimulation of the glioma cells with histamine and hydrocortisone elicited oscillating increases of free intracellular calcium ions. The cells showed a fast increase of intracellular calcium that was undulant on a kind of a plateau in a very typical manner and could be reproduced several times (Fig. 4). In summary, 129 cells of the U87MG and the U373MG human glioblastoma cell lines were tested with histamine and 72 cells of these two cell lines were tested for their response upon hydrocortisone stimulation. One hundred percent of the tested cells displayed the described calcium response (Fig. 4). 
Fig. 5 Drugs of group 4 that cause decelerated calcium increases are summarized. The table shows the drugs and the number of cells tested positively out of the total number of tested cells. a-c The graphics below demonstrate typical experimental results upon the exposure of promethazine, diazepam, and metamizol to the human glioblastoma cells. The bars indicate the duration of substance administration according to the details mentioned in "Methods"

\begin{tabular}{|l|l|l|}
\hline Substances of group 4 & $\begin{array}{l}\text { Positive calcium } \\
\text { signal in U87MG cells }\end{array}$ & $\begin{array}{l}\text { Positive calcium } \\
\text { signal in U373MG } \\
\text { cells }\end{array}$ \\
\hline Metoclopramide & $25 / 48$ cells $(17+13+18)$ & not tested \\
\hline Metamizol & $57 / 57$ cells $(22+17+18)$ & not tested \\
\hline Promethazine & $40 / 43$ cells $(7+21+15)$ & $18 / 18$ cells $(4+6+8)$ \\
\hline Diazepam & $45 / 45$ cells $(14+16+15)$ & $16 / 27$ cells $(8+10+9)$ \\
\hline cafedrin/theodrenalin (combi) & $41 / 41$ cells $(14+14+13)$ & not tested \\
\hline
\end{tabular}
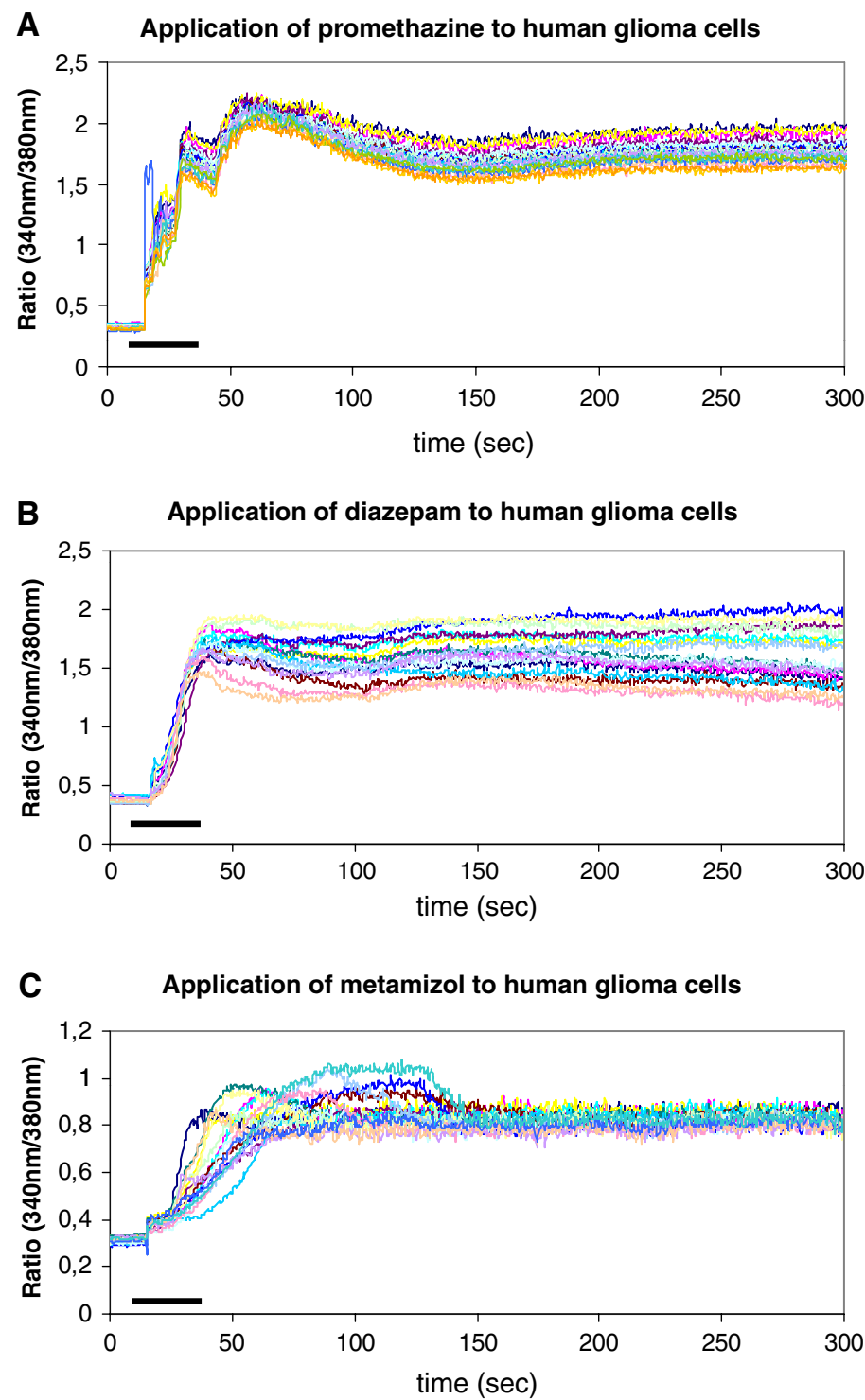

\section{Calcium signals of type 4}

The type 4 calcium signal of the group 4 drugs is characterized by a slowly increasing intracellular concentration of free calcium ions (Table 2, Fig. 1, 5). This slowly rising intracellular calcium ion level is caused by a very slow increase of conductibility of the cellular membrane or a modulation of calcium extrusion mechanisms (Möller 2002). Substances of group 4 are metoclopramide, metamizol, promethazine, and diazepam. The combination of cafedrin and theodrenalin shows components of a type 2 response and a type 4 response. Two hundred and eight 
Fig. 6 Theophylline and clonidine were defined as group 5 of medical drugs according to the appearance of their calcium signal that resembles the signals of groups 3 and 4 . The table shows the tested substances. a, b The graphics show the delayed start of the intracellular calcium rise and the grafted calcium oscillations. The bars indicate the duration of substance administration according to the details mentioned in "Methods"

\begin{tabular}{|l|l|l|}
\hline Substances of group 5 & $\begin{array}{l}\text { Positive calcium } \\
\text { signal in U87MG cells }\end{array}$ & $\begin{array}{l}\text { Positive calcium } \\
\text { signal in U373MG } \\
\text { cells }\end{array}$ \\
\hline Theophylline & $46 / 46$ cells $(15+19+12)$ & not tested \\
\hline Clonidine & $32 / 35$ cells $(11+12+12)$ & $11 / 16$ cells $(8+3+5)$ \\
\hline
\end{tabular}
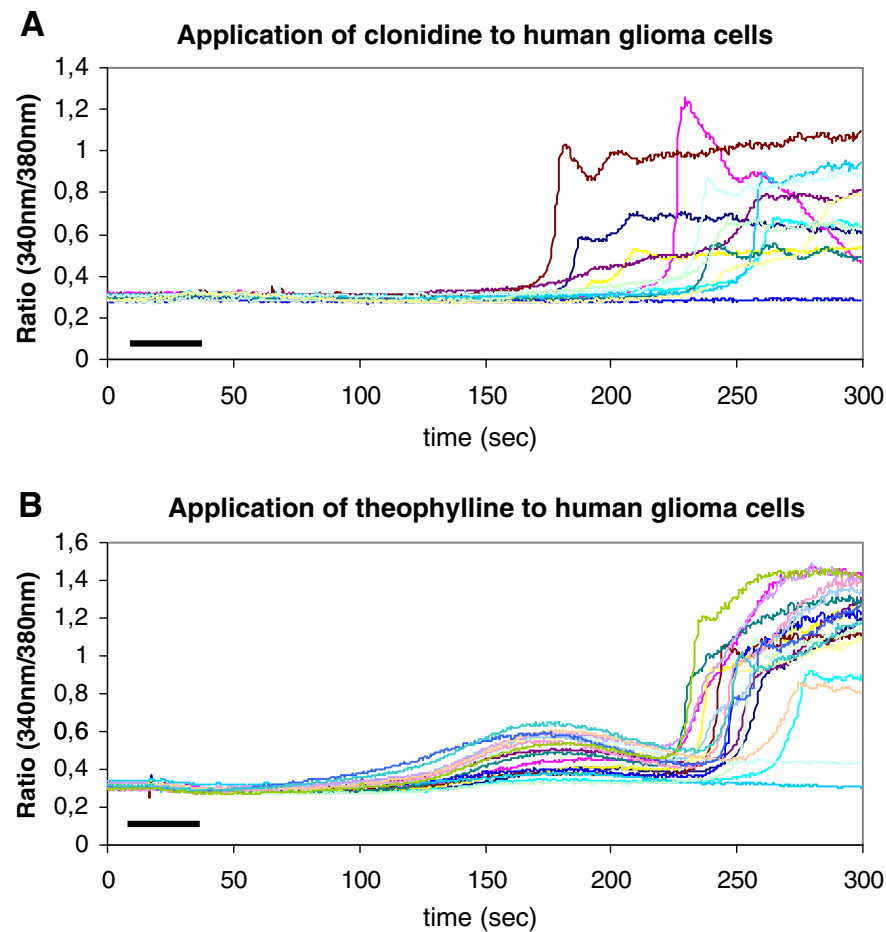

cells of the tested U87MG cells $(n=234)$ and 34 cells of the tested U343MG $(n=45)$ repeatedly showed a positive response resembling the type 4 signal (Fig. 1, 5).

Calcium answers with features of type 3 and type 4 signals

Group 5 contains the drugs clonidine and theophylline. In our glioblastoma cells, the calcium responses could not be classified into groups 1 through 4 because the calcium signal was of a mixed type 3 and 4 . This was repeatedly shown in our experiments with the U373MG and the U87MG glioblastoma cells (Table 2, Fig. 1, 6). Fourty six cells of the U87MG line were tested with theophylline and showed a positive response (Fig. 6). Thirty-five U87MG cells were investigated upon the administration of clonidine to the perfusing bath solution; 32 of these showed the positive reaction (Fig. 6). Eleven cells from 16 tested U373MG cells reacted in the same manner to the application of clonidine (Fig. 6).

\section{Group 6 of substances}

Into group 6, all the ion preparations with an increase of the intracellular calcium level by administration of free ion solutions were included. The resulting calcium signal was called "ion type" signal irrespective of the mechanisms responsible for the signal (Table 2). The application of extracellular calcium caused the intracellular stores to be refilled, accompanied by a transient increase of cytosolic free calcium ions (Fig. 7). The application of potassium ions caused a membrane depolarization, thereby causing extracellular calcium ions to pass through voltage-gated calcium channels and again transiently increasing the concentration of intracellular free calcium ions (Fig. 7). The sodium ions passed from the extra- to the intracellular compartment and were exchanged by calcium ions during the clearance process (Fig. 7). All cells of the two glioblastoma cell lines showed the above mentioned cellular responses (Fig. 7).

Negative control with HEPES buffer and dexamethasone

Into group 7, the non-reactive substances, the negative control HEPES and the cortisol derivative dexamethasone were included (Table 2, Fig. 8).

As was expected, the negative control with the application of the isotonic HEPES buffer itself did not cause any change of the intracellular calcium ion baseline. Thirty-seven 
cells of the U87MG glioblastoma cell line and 29 cells of the U373MG glioblastoma cell line were tested in three independent experiments (Fig. 8). In accordance with that, the application of dexamethasone did not result in any rise or decline of the intracellular calcium level. Fourty three cells of the U87MG glioblastoma cell line and 23 cells of the U373MG glioblastoma cell line were tested (Fig. 8).

\section{Discussion}

Calcium ions are a highly versatile intracellular signal that acts as a means of information proceeding within the cell's cytoplasm to regulate many different cellular processes, like cellular metabolism, gene transcription, proliferation, or cellular movement (Fig. 9) (Bernstein et al. 1996; Fatatis et al. 1994; Friel 1995; Möller 2002; Verkhratsky et al. 1998; Färber and Kettenmann 2006; Verkhratsky and Shmigol 1996; Perea and Araque 2005; Verkhtatsky and Steinhäuser 2000; Berridge et al. 2003).

Fast intracellular calcium peaks regulate fast reactions (Berridge et al. 2003). Slower calcium increases are involved in prolonged signaling chains. Calcium increases are regulated by a complex network of mechaisms. These include the influx from the extracellular space via voltagegated calcium channels of the cellular membrane. G-protein coupled receptors can increase the cytoplasmic calcium concentration by release of calcium ions from intracellular stores via store operated calcium channels. Receptor operated calcium channels may cause the influx of calcium ions from the extracellular space or from intracellular stores (Fig. 9) (Berridge et al. 2003). After initialization of intracellular down-stream processes free intracellular calcium ions are toxic to the cell. Therefore, the cell has mechanisms of calcium clearance to reduce the calcium concentration down to a non-toxic level. Calcium ions are transported out of the cell or into the intracellular calcium stores by $\mathrm{Ca}^{2+}$ ATPases (Fig. 9). Other ion pumps and exchangers of cellular membranes, like the $\mathrm{Na}^{+}-\mathrm{Ca}^{2+}$-exchanger, the $\mathrm{H}^{+}-\mathrm{Ca}^{2+}$ exchanger, or the $\mathrm{NA}^{+}-\mathrm{K}^{+}$-ATPase support the maintenance of the intracellular ion milieu (Fig. 9).

Neurons and glial cells are known for the crouded expression of cell surface ion channels and neurotransmitter receptors that regulate the intracellular calcium level in order to regulate the activation of the complex down-stream processes (Albrecht et al. 2001; Verkhratsky and Shmigol 1996).

This publication describes for the first time a fast and efficient screening system to evaluate the expression of ion channels and neurotransmitter receptors on human glioma cells that are linked to the intracellular calcium signaling mechanisms.

Patients with human glioblastomas mostly belong to the elder population according to the epidemiological profile of the disease. They get many different drugs for the treatment of high blood pressure, heart disease, kidney dysfunction, and more. They receive the drug dexamethasone for the reduction of the peritumoral brain edema. Especially older patients may suffer from some mental confusion that sometimes requires the administration of sedative drugs. Depending on the multitude of cerebral signaling pathways, one can imagine an effect of medical drugs on glioma biology in case the tumor would express any of the responsible receptors or ion channels.

Human glioma cells are known to express receptors for neurokinins, VIP, and substance P (Bordey et al. 1994; Nielsen et al. 1990; Sharma et al. 2001; Sokolowska and Nowak 2008; Cooper et al. 1988; Luo et al. 1996; Grynkiewicz et al. 1985; Eistetter et al. 1992; Łazarczyk et al. 2007). This was shown in our experiments as well and could serve as positive control for the induction of intracellular calcium signals. Another study showed human glioma cells to express cell-surface receptors for angiotensin II, bradykinin, histamine, substance $\mathrm{P}$, norepinephrine, and serotonin (Weydt et al. 1997).

The HEPES buffer solution corresponds to the extracellular fluid within the CNS. This means, HEPES has to be electroneutral without any activation of intracellular downstream events upon cellular exposure. This was proved by our experiments as well. Twenty-five medical drugs were tested for their ability to elicit intracellular calcium signals in human glioma cells. Most of the drugs are known to activate distinct cell-surface receptors or ion channels. We found all drugs expect for one to elicit intracellular calcium answers (Table 2). According to the anticipated involved calcium pathways, the intracellular calcium responses were summarized into seven types and the responsible drugs were organized into seven groups. Type 1 of calcium signals is elicited by haloperidol, urapidil, droperidol, dimetindene, and phenytoin. Haloperidol blocks dopamine receptors as well as muscarinic receptors and adrenergic receptors. Droperidol, another neurolepticum, binds to D2 dopamine receptors and with a lower affinity to D3 dopamine receptors, 5-HT 2 receptors, and alpha-1-adrenoreceptors, whereas dimetindene binds $\mathrm{H} 1$ histamine receptors. Alpha-1-adrenoreceptors are G-protein coupled receptors and cause in intracellular calcium ion increase via the G-protein-inositol-1,4,5-triphosphate-cascade (Fig. 9). The putative pathways of calcium signaling induction by these drugs currently are not known and require further research. Urapidil blocks alpha-1-adrenoreceptors but stimulates central 5-hydroxytryptamine 1A (5-HT 1A) receptors. Serotonin receptors can activate inwardly or outwardly rectifying potassium currents as was shown for neurons of the substantia gelatinosa (Abe et al. 2009). These currents can change the cellular membrane potential and thereby activate voltage-gated calcium channels for a calcium 


\begin{tabular}{|l|l|l|}
\hline Substances of group 6 & $\begin{array}{l}\text { Positive calcium } \\
\text { signal in U87MG cells }\end{array}$ & $\begin{array}{l}\text { Positive calcium } \\
\text { signal in U373MG } \\
\text { cells }\end{array}$ \\
\hline Calcium ions & $39 / 39$ cells $(9+16+14)$ & $32 / 32$ cells $(12+15+5)$ \\
\hline Potassium ions & $\begin{array}{l}54 / 54 \text { cells } \\
(15+14+15+10)\end{array}$ & $19 / 19$ cells $(9+4+6)$ \\
\hline Sodium ions & $43 / 50$ cells $(17+19+14)$ & not tested \\
\hline
\end{tabular}
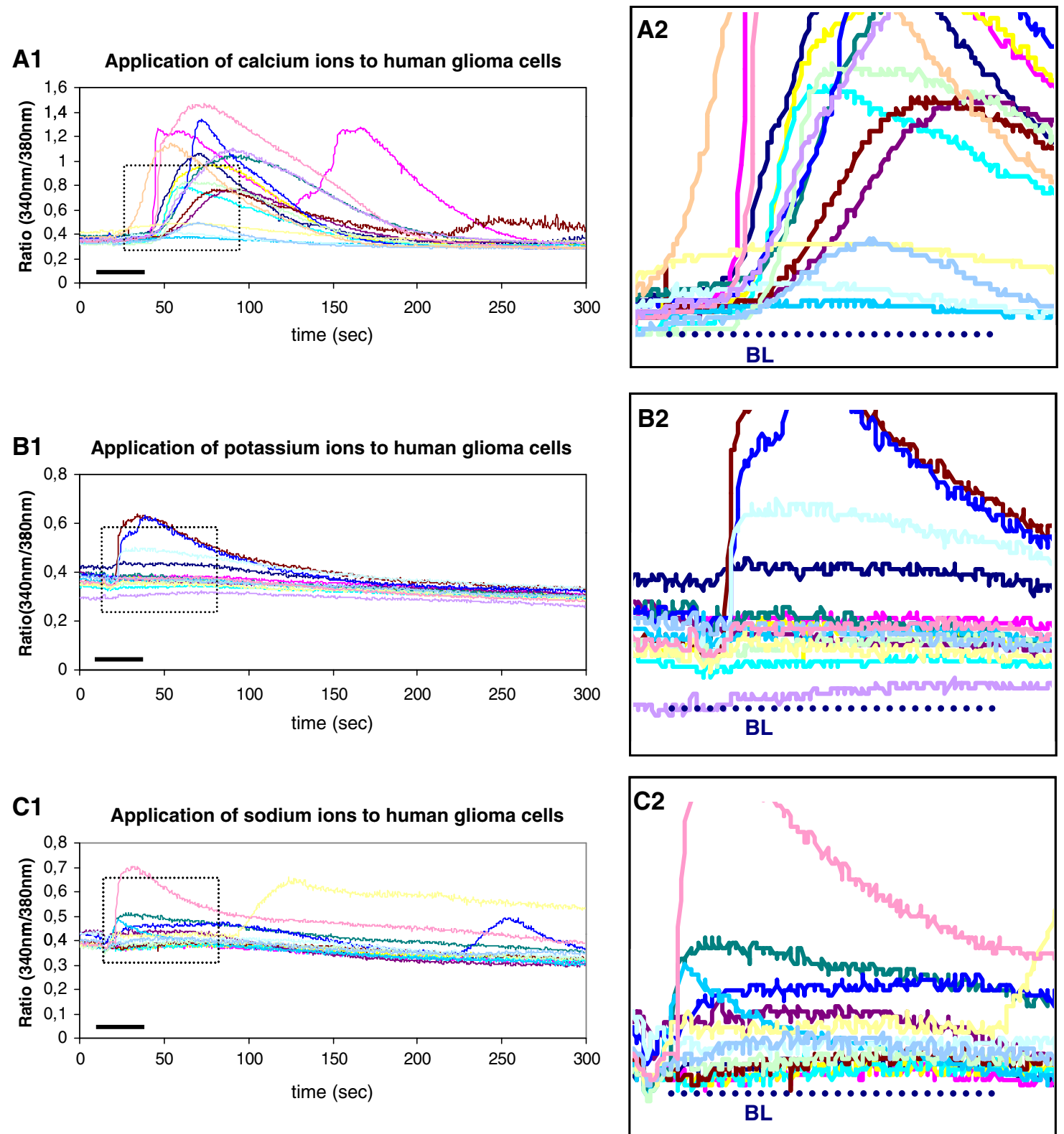

influx into the cell. To the voltage-gated calcium channels belong the L-type calcium channels $\left(\mathrm{Ca}_{\mathrm{V}} 1.1, \mathrm{Ca}_{\mathrm{V}} 1.2\right.$, $\left.\mathrm{Ca}_{\mathrm{V}} 1.3, \mathrm{Ca}_{\mathrm{V}} 1.4\right)$, the P/Q-type calcium channels $\left(\mathrm{Ca}_{\mathrm{V}} 2.1\right)$, the N-type calcium channels $\left(\mathrm{Ca}_{\mathrm{V}} 2.2\right)$, the R-type calcium channels $\left(\mathrm{Ca}_{\mathrm{V}} 2.3\right)$, and the T-type calcium channels $\left(\mathrm{Ca}_{\mathrm{V}} 3.1, \mathrm{Ca}_{\mathrm{V}} 3.2, \mathrm{Ca}_{\mathrm{v}} 3.3\right)$ (Berridge et al. 2003). Which of these channels are activated and what their activation induces in the glioma cell, has to be determined in the future. The calcium signal caused by all of these drugs is characterized by its transient nature with a fast initial rise and a rapid falling component. Transiently open intracellular stores and/or open cell membrane channels cause this rapid intracellular response. Down-stream processes are initiated quickly. The exact nature of these processes within 
4 Fig. 7 All ion solutions are summarized into group 6 because of their ionic properties irrespective of the putative mechanism of intracellular calcium rise. The table above indicates an intracellular calcium ncrease upon the application of either ion solution. a1, a2 As explained within the discussion section, an extracellular calcium solution causes the diffusion of calcium ions into the cells towards the concentration gradient. Upon intracellular arrival of calcium ions, cellular mechanisms work towards the maintenance of the low non-toxic basal calcium level. ATP-dependent $\mathrm{Ca}^{2+}$-pumps transport the calcium ions into the intracellular stores or into the extracellular compartment. a1 The whole course of the calcium signal is illustrated. a2 The magnification of A1 demonstrates the different levels of intracellular calcium rise in dependence on the individual status of the cell. The bars indicate the duration of substance administration according to the details of the methods section. b1, b2 A highly extracellular concentration of potassium ions causes a depolarization of the cellular membrane, which is followed subsequently by a calcium ion influx through voltage dependent calcium channels. The subsequent calcium ion clearance mechanisms function as mentioned before by activation of the ATP-dependent calcium pumps. b2 The magnification of $\mathbf{b} \mathbf{1}$ shows the individual levels of the intracellular calcium increase. The bars indicate the duration of substance administration according to the details of the methods section. c1, c2 The administration of a highly concentrated sodium solution causes the influx of sodium ions into the cell down the concentration gradient. A high intracellular sodium concentration is toxic to the cells as well. Therefore, the cells use the sodium-calcium exchanger $\left(\mathrm{Na}^{+}-\mathrm{Ca}^{2+}\right.$-exchanger) to remove additional sodium ions from the intracellular compartment by exchange with extracellular calcium ions. This causes a rise of intracellular calcium ions that are cleared again by ATP-dependent calcium pumps. The bars indicate the duration of substance administration according to the details mentioned in "Methods"

human glioma cells is not known yet and is subject of ongoing research. The high concentration of free intracellular calcium ions is cleared immediately from the cytoplasm by a complex network of mechanisms (Fig. 9). Substances that cause type 2 calcium responses are summarized in Table 2. Whereas substance $\mathrm{P}$, vasoactive intestinal polypeptide, and the neurokinins $\mathrm{A}$, and B are known to influence glioma biology (Bordey et al. 1994; Sokolowska and Nowak 2008; Cooper et al. 1988; Luo et al. 1996; Eistetter et al. 1992; Łazarczyk et al. 2007), thiamazole, physostigmin, and epinephrine were not known to elicit calcium signals in human glioma cells or to influence their proliferation or migration. Calcium signals in a former study were not classified into groups, but the calcium signal induced by norepinephrine was similar to our signal elicited by epinephrine (Weydt et al. 1997). The combined preparation of cafedrin and theodrenalin induces a signal with a fast initial rise and the typical "calcium shoulder" like in type 2 calcium signals that is merged to a "calcium tail" typical for type 4 calcium responses. The combined drug is used amongst others during anesthesia to control the blood pressure. As our results clearly demonstrate, this drug acts onto several calcium signaling pathways and could have several effects on human glioblastoma cells. Physostigmin stimulated both, nicotinic and muscarinic receptors. Muscarinic receptors M1-M3 belong to the group of G-protein coupled receptors like the substance $\mathrm{P}$ receptor NK3 (Berridge et al. 2003). Their signals are transduced by a variety of G-proteins, like $\mathrm{G}_{\mathrm{q} \alpha}, \mathrm{G}_{11 \alpha}, \mathrm{G}_{14 \alpha}, \mathrm{G}_{16 \alpha}$, and $\mathrm{G}_{\beta \gamma}$, followed by the activation of distinct phospholipases type $\mathrm{C}$ (Berridge et al. 2003). The calcium signal induced by this group of substances results from an initial influx of calcium ions from intracellular stores and/or from the extracellular medium via cell membrane channels. This is followed by a slower influx mediated by receptor operated calcium channels or store operated calcium channels.

Very characteristic oscillating calcium responses were elicited by the administration of histamine and hydrocortisone to our human glioblastoma cells U373MG and U87MG. This was known to occur in vascular endothelial cells upon the exposure of histamine (Zhu et al. 2008; Barajas et al. 2008; Lefranc et al. 2006; Hernández-Angeles et al. 2001). Also neurons can show oscillations of the intracellular calcium level after the administration of histamine (Hegedus et al. 2004). Steroid hormones are known for their effect on the activity of calcium-activated potassium channels (Chang and Zhang 2008), but it was not known that they could induce calcium responses. Cortisol was shown to suppress voltage-gated calcium channels in prolactin cells of the tilapia (Hyde et al. 2004). In our experiments, hydrocortisone repeatedly elicited the above mentiomed calcium oscillations in a very stringent manner. Glucocorticoids have been shown to stimulate the sodium channel expression in astrocytes (Yarowsky et al. 1994). They could have similar effects on human glioma cells. Their exact function is unknown to date.

The so called "ion type" of calcium signals was defined by the applied substance consisting of an ion solution like a sodium ion solution, a potassium ion solution, or a calcium ion solution. According to the glioblastoma cells' individual condition, some cells reacted with an intracellular calcium signal and some cells did not. The mechanisms of calcium rise within the cytoplasm were very different for every ion type. The extracellular exposure of a high molar calcium solution causes the free calcium ions to diffuse along the electrochemical concentration gradient into the cells (Fig. 7, 9). The manner of the intracellular calcium uptake is characterized by the cells' condition prior to the calcium administration. This explains the very different course of individual intracellular calcium increases, seen in Fig. 7a. Some cells showed a strong and immediate calcium uptake and some cells reacted twice after an interposed calcium clearance. Other cells reacted with a delay in comparison to strongly reacting cells. But despite different calcium uptake features, all cells showed a subsequent decrease in cytoplasmic calcium ions that was caused by the transport of the ions into intracellular calcium stores or into the extracellular space. The mechanism of the calcium increase upon the 
Fig. 8 Group 7 consists of the negative control solution HEPES and the drug dexamethasone. Both substances were not able to induce any calcium signals as is visualized in the table and in the two graphics $(\mathbf{a}, \mathbf{b})$ below. The numbers in brackets within the table show the number of cells tested in summary. The bars indicate the duration of substance administration according to the details mentioned in "Methods"

\begin{tabular}{|l|l|l|}
\hline Substances of group 7 & $\begin{array}{l}\text { Positive calcium } \\
\text { signal in U87MG cells }\end{array}$ & $\begin{array}{l}\text { Positive calcium } \\
\text { signal in U373MG cells }\end{array}$ \\
\hline HEPES buffer & $0 / 37$ cells $(16+12+9)$ & $0 / 29$ cells $(8+9+12)$ \\
\hline Dexamethasone & $0 / 43$ cells $(16+14+13)$ & $0 / 23$ cells $(10+4+9)$ \\
\hline
\end{tabular}

A
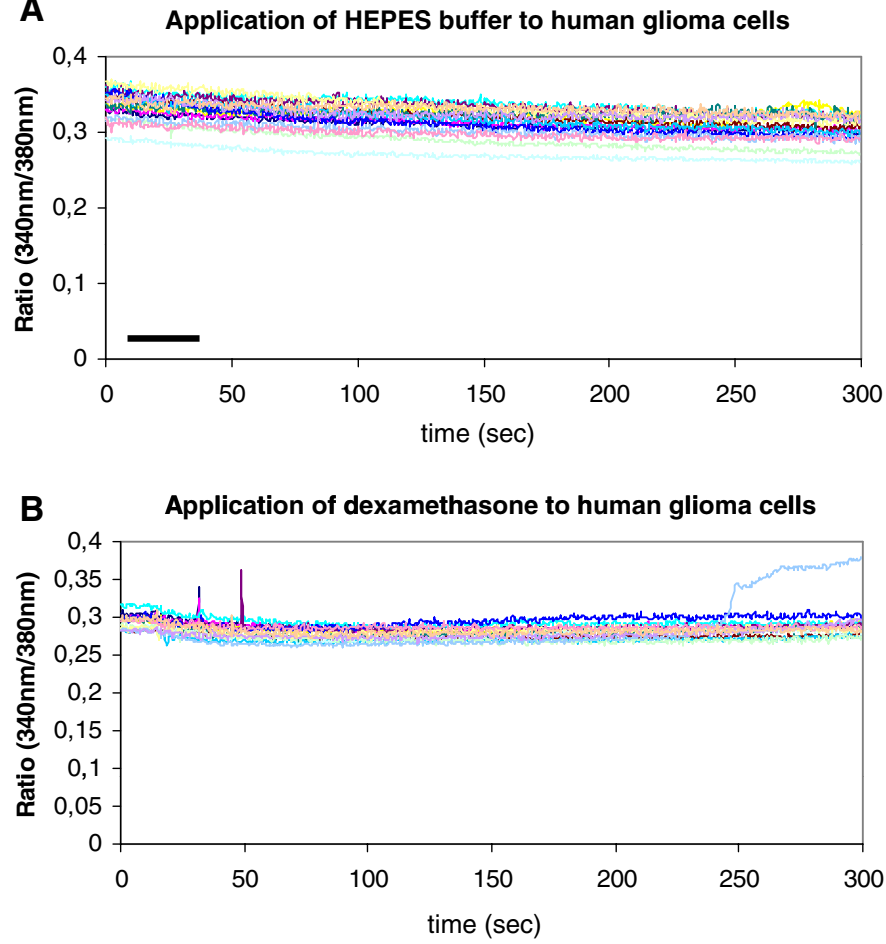

exposure of potassium ions differed significantly from the mechanisms upon calcium ion application. High molar potassium ion solutions cause a membrane depolarization in human glial and human glioma cells as was shown several times before (Fig. 9) (Bernstein et al. 1996; Labrakakis et al. 1998a, b; Kettenmann et al. 1984). The extent of membrane depolarization in a cell culture or in cells of an acute brain slice swings around the Gaussian distribution. Our experiments showed very clearly, all cells reacted with an influx of calcium ions via voltage-gated calcium channels with a different amplitude in distinct cells (Fig. 7b, 9). Another mechanism is responsible for the intracellular calcium increase upon the exposure of a high molar sodium ion solution. In our study, the sodium solution was hypermolar in comparison to the sodium ion concentration of the cytoplasm. This caused an influx of sodium ions into the cell along the concentration gradient as was known for calcium ions as well. Fourty-three cells of our tested 50 U87MG glioblastoma cells showed this effect. To decrease the intracellular sodium content, the cells use sodium pumps and sodium exchangers. The sodium-calcium exchanger $\left(\mathrm{Na}^{+}-\mathrm{Ca}^{2+}\right.$-exchanger $)$ is the most common and best known member of this family. By the transportation of sodium ions out of the cell into the extracellular fluid, the cell takes up calcium ions from extracellular. This temporarily increases the intracellular calcium concentration. These ions will be transported secondarily into intracellular stores or into the extracellular fluid by ATP-dependent calcium pumps to maintain the non-toxic calcium level after the initialization of down-stream processes (Fig. 9). These complex mechanisms enable the cell, to maintain its free ion content upon the eventual increase in the extracellular milieu.

The presented screening procedure enables the identification of many cellular receptors and ion channels on human glioma cells. All of the tested substances have receptors or ion channels on glioma cells except for the drug dexamethasone.

Despite this surprising result, we thought initially that glioma cells would express only a small subset of receptors on their surfaces, but exactly the opposite proved true. Whether all of these receptors have an supportive or inhibitory effect on glioma proliferation and glioma invasion is not known to date. But further experiments concentrating on each of these systems will solve this question in the future. 
Fig. 9 Scheme of putative calcium signaling within the glioma cells The figure illustrates different pathways of intracellular calcium ion increases, stores as well as outflux mechanisms. The effects of calcium signals are for higher rates of cellular metabolism, cellular gene transcription and protein synthesis, as well as proliferation and migration

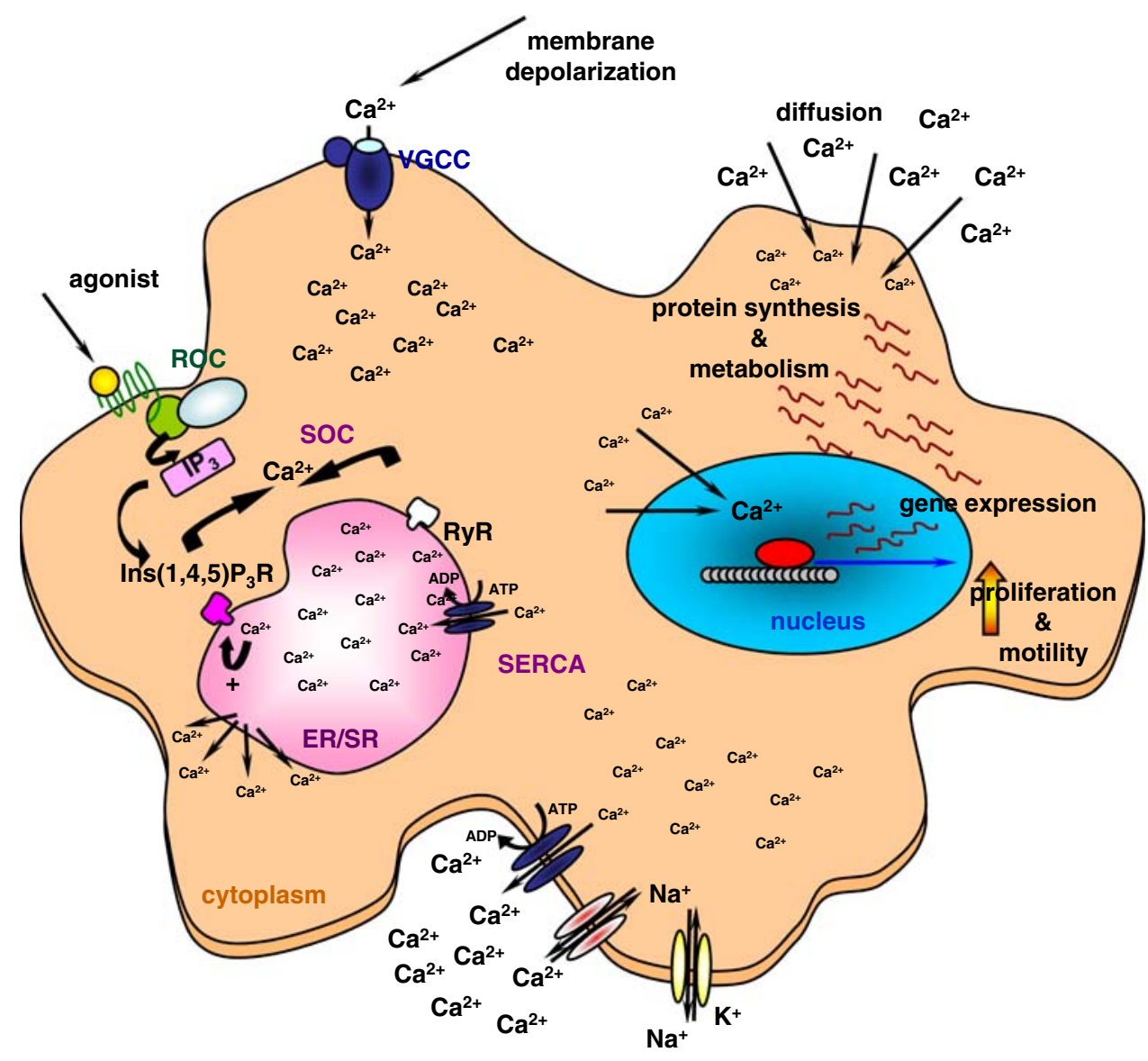

Acknowledgments This work was supported by LUBOM Thuringia of the Ministry for Science, Research, and Art (2005) and by the Trust of Neurosurgical Research of the German Society of Neurosurgery to Susanne A. Kuhn (2005, 2007, and 2008) and to Rupert Reichart (2007).

\section{References}

Abe K, Kato G, Katafuchi T, Tamae A, Furue H, Yoshimura M (2009) Responses to 5-HT in morphologically identified neurons in the rat substantia gelatinosa in vitro. Neuroscience 159:316-324. doi:10.1016/j.neuroscience.2008.12.021

Albrecht MA, Colegrove SI, Hongpaisan J, Pivovarova NB, Andrews SB, Friel DD (2001) Multiple modes of calcium-induced calcium release in sympathetic neurons I: attenuation of endoplasmic reticulum $\mathrm{Ca} 2+$ accumulation at low $[\mathrm{Ca} 2+](\mathrm{i})$ during weak depolarization. J Gen Physiol 118(1):83-100. doi:10.1085/jgp.118. 1.83

Anderson CM, Nedergaard M (2003) Astrocyte-mediated control of cerebral microcirculation. Trends Neurosci 26(7):340-344. doi:10.1016/S0166-2236(03)00141-3

Baimbridge KG, celio MR, Rogers JH (1992) Calcium-binding proteins in the nervous system. Trends Neurosci 15(8):303-308. doi:10.1016/0166-2236(92)90081-I

Barajas M, Andrade A, Hernandez-Hernandez O, Felix R, Arias-Montaño JA (2008) Histamine-induced Ca2+ entry in human astrocytoma U373 MG cells: evidence for involvement of store-operated channels. J Neurosci Res 86(15):3456-3468. doi:10.1002/jnr. 21784
Bardo S, Cavazzini MG, Emptage N (2006) The role of the endoplasmic reticulum $\mathrm{Ca} 2+$ store in the plasticity of central neurons. Trends Pharmacol Sci 27(2):78-84. doi:10.1016/j.tips.2005. 12.008

Barres BA (2008) The mystery and magic of glia: a perspective on their roles in health and disease. Neuron 60(3):430-440. doi:10.1016/j.neuron.2008.10.013

Bender AS, Hertz L (1987) Pharmacological characteristics of diazepam receptors in neurons and astrocytes in primary cultures. J Neurosci Res 18(2):366-372. doi:10.1002/jnr.490180215

Bernstein M, Myons SA, Möller T, Kettenmann H (1996) Receptormediated calcium signalling in glial cells from mouse corpus callosum slices. J Neurosci Res 46(2):152-163. doi:10.1002/(SICI)1097-4547(19961015)46:2<152::AID-JNR3>3.0.CO;2-G

Berridge MJ (2008) Inositol triphosphate and calcium signalling mechanisms. Biochim Biophys Acta. doi:10.1016/j.bbamcr.2008.10.005

Berridge MJ, Bootman MD, Roderick HL (2003a) Calcium signalling: dynamics, homeostasis and remodelling. Nat Rev Mol Cell Biol 4(7):517-529. doi:10.1038/nrm1155

Berridge MJ, Bootman MD, Roderick HL (2003b) Calcium signalling: dynamics, homeostasis and remodelling. Natl Rev 4:517-529

Blaustein MP, Golovina VA (2001) Structural complexity and functional diversity of endoplasmic reticulum $\mathrm{Ca} 2+$ stores. Trends Neurosci 24(10):602-608. doi:10.1016/S0166-2236(00)01891-9

Bordey A, Feltz P, Trouslard J (1994) Mobilization of intracellular calcium by substance $P$ in a human astrocytoma cell line (U373MG). Glia 11(3):277-283. doi:10.1002/glia.440110309

Castillo CA, Albasanz JL, Fernández M, Martín M (2007) Endogenous expression of adenosine A1, A2 and A 3 receptors in rat C6 glioma cells. Neurochem Res 32(6):1056-1070. doi:10.1007/s11064006-9273-x 
Chang K, Zhang Lubo (2008) Review article: steroid hormones and uterine vascular adaptation to pregnancy. Reprod Sci 15(4):336348. doi:10.1177/1933719108317975

Clapham DE (2007) Calcium signaling. Cell 131(6):1047-1058. doi:10.1016/j.cell.2007.11.028

Cooper DM, Caldwell KK, Perez-Reyes E, Ahlijanian MK, Schlegel W (1988) Interactions between neurotransmitters that regulate cAMP and intracellular Ca2+ levels in the CNS. Adv Exp Med Biol 236:217-227

Eistetter HR, Mills A, Brewster R, Alouani S, Rambosson C, Kawashima E (1992) Functional characterization of neurokinin-1 receptors on human U373MG astrocytoma cells. Glia 6(2):89-95. doi:10.1002/glia.440060203

Färber K, Kettenmann H (2006) Functional role of calcium signals for microglial function. Glia 54(7):656-665. doi:10.1002/glia.20412

Fatatis A, Holtzclaw LA, Avidor R, Brennemann DE, Russell JT (1994) Vasoactive intestinal peptide increases intracellular calcium in astroglia: synergism with alpha-adrenergic receptors. Proc Natl Acad Sci USA 91(6):2036-2040. doi:10.1073/ pnas.91.6.2036

Friel DD (1995) Calcium oscillations in neurons. Ciba Found Symp 188:210-223

Gordon GR, Choi HB, Rungta RL, Ellis-Davies GC, MacVicar BA (2008) Brain metabolism dictates the polarity of astrocyte control over arterioles. Nature 456(7223):745-749. doi:10.1038/ nature 07525

Grynkiewicz G, Poenie M, Tsien RY (1985) A new generation of Ca2+ indicators with greatly improved fluorescence properties. J Biol Chem 260(6):3440-3450

Han JZ, Lin W, Lou SJ, Chen YZ (2002) Norepinephrine-induced calcium mobilization in C6 glioma cells. Acta Pharmacol Sin 23(6):490-496

Hegedus E, Kaslin J, Hiripi L, Kiss T, Panula P, Elekes K (2004) Histaminergic neurons in the central and peripheral nervous system of gastropods (Helix, Lymnaea): an immunocytochemical, biochemical, and electrophysiological approach. J Comp Neurol 475(3):391-405. doi:10.1002/cne.20171

Hernández-Angeles A, Soria-Jasso LE, Ortega A, Arias-Montaño JA (2001) Histamine H1 receptor activation stimulates mitogenesis in human astrocytoma U373 MG cells. J Neurooncol 55(2):8189. doi:10.1023/A:1013338515229

Hösli L, Hösli E (1987) Receptors for dopamine and serotonin on astrocytes of cultured rat central nervous system. J Physiol (Paris) 82(4):191-195

Hösli L, Hösli E, Schneider U, Wiget W (1984) Evidence for the existence of histamine $\mathrm{H} 1$ - and $\mathrm{H} 2$-receptors on astrocytes of cultured rat central nervous system. Neurosci Lett 48(3):287-291. doi:10.1016/0304-3940(84)90052-1

Hyde GN, Seale AP, Grau EG, Borski RJ (2004) Cortisol rapidly suppresses intracellular calcium and voltage-gated calcium channel activity in prolactin cells of the tilapia (Oreochromis mossambicus). Am J Physiol Endocrinol Metab 286(4):E626-E633. doi:10.1152/ajpendo.00088.2003

Iadecola C, Nedergaard M (2007) Glial regulation of the cerebral microvasculature. Nat Neurosci 10(11):1369-1376. doi:10.1038/ $\mathrm{nn} 2003$

Iino $\mathrm{M}$ (2008) Identification of new functions of $\mathrm{Ca} 2+$ release from intracellular stores in central nervous system. Biochem Biophys Res Commun 369(1):220-224. doi:10.1016/j.bbrc.2007.11.090

Jaiswal JK (2001) Calcium-how and why? J Biosci 26(3):357-363. doi:10.1007/BF02703745

Putney JW Jr (2007) New molecular players in capacitative Ca2+ entry. J Cell Sci 120(Pt12):1959-1965. doi:10.1242/jcs.03462

Kettenmann H, Backus KH, Schachner M (1984) Aspartate, glutamate and gamma-aminobutyric acid depolarize cultured astrocytes. Neurosci Lett 52(1-2):25-29. doi:10.1016/0304-3940(84)90345-8
Kirischuk S, Tuschick S, Verkhratsky A, Kettenmann H (1996) Calcium signalling in mouse Bergmann glial cells mediated by alpha1-adrenoreceptors and $\mathrm{H} 1$ histamine receptors. Eur J Neurosci 8(6):1198-1208. doi:10.1111/j.1460-9568.1996.tb01288.x

Labrakakis C, Patt S, Hartmann J, Kettenmann H (1998a) Functional GABA(A) receptors on human glioma cells. Eur J Neurosci 10(1):231-238. doi:10.1046/j.1460-9568.1998.00036.x

Labrakakis C, Patt S, Hartmann J, Kettenmann H (1998b) Glutamate receptor activation can trigger electrical activity in human glioma cells. Eur J Neurosci 10(6):2153-2162. doi:10.1046/j.14609568.1998.00226.x

Łazarczyk M, Matyja E, Lipkowski A (2007) Substance P and its receptors-a potential target for novel medicines in malignant brain tumour therapies (mini-review). Folia Neuropathol 45(3):99-107

Lefranc F, Yeaton P, Brotchi J, Kiss R (2006) Cimetidine, an unexpected anti-tumor agent, and its potential for the treatment of glioblastoma. Int J Oncol 28(5):1021-1030 (review)

Lovick TA, Brown LA, Key BJ (2005) Neuronal activity-related coupling in cortical arterioles: involvement of astrocyte-derived factors. Exp Physiol 90(1):131-140. doi:10.1113/expphysiol. 2004.028811

Luo W, Sharif TR, Sharif M (1996) Substance P-induced mitogenesis in human astrocytoma cells correlates with activation of the mitogen-activated protein kinase signaling pathway. Cancer Res 56(21):4983-4991

Lyons SA, Chung WJ, Weaver AK, Ogunrinu T, Sontheimer H (2007) Autocrine glutamate signaling promotes glioma cell invasion. Cancer Res 67(19):9463-9471. doi:10.1158/0008-5472.CAN07-2034

Matyash M, Matyash V, Nolte C, Sorrentino V, Kettenmann H (2002) Requirement of functional ryanodine receptor type 3 for astrocyte migration. FASEB J 16(1):84-86

McCoy E, Sontheimer H (2007) Expression and function of water channels (aquaporins) in migrating malignant astrocytes. Glia 55(10):1034-1043. doi:10.1002/glia.20524

Möller T (2002) Calcium signaling in microglial cells. Glia 40(2):184 194. doi: $10.1002 /$ glia. 10152

Nielsen FC, Gammeltopf S, Westermark B, Fahrenkrug J (1990) High affinity receptors for vasoactive intestinal peptide on a human glioma cell line. Peptides 11(6):1225-1231. doi:10.1016/01969781(90)90156-Y

Olsen ML, Schade S, Lyons SA, Amaral MD, Sontheimer H (2003) Expression of voltage-gated chloride channels in human glioma cells. J Neurosci 23(13):5572-5582

Parekh AB (2006) On the activation mechanism of store-operated calcium channels. Pflugers Arch 453(3):303-311. doi:10.1007/ s00424-006-0089-y

Parekh AB (2008) Store-operated channels: mechanisms and function. J Physiol 586(13):3033. doi:10.1113/jphysiol.2008.156885

Parekh AB, Penner R (1997) Store depletion and calcium influx. Physiol Rev 77(4):901-930

Perea G, Araque A (2005) Glial calcium signaling and neuron-glia communication. Cell Calcium 38:375-382. doi:10.1016/j.ceca. 2005.06.015

Peters O, Schipke CG, Hashimoto Y, Kettenmann H (2003) Different mechanisms promote astrocyte $\mathrm{Ca} 2+$ waves and spreading depression in the mouse neocortex. J Neurosci 23(30):9888-9896

Putney JW Jr (1997) Type 3 inositol 1, 4, 5-triphosphate receptor and capacitative calcium entry. Cell Calcium 21(3):257-261. doi:10.1016/S0143-4160(97)90050-6

Schipke CG, Boucsein C, Ohlemeyer C, Kirchhoff F, Kettenmann H (2002) Astrocyte Ca2+ waves trigger responses in microglial cells in brain slices. FASEB J 16(2):255-257

Sharma A, Walters J, Gozes Y, Fridkin M, Brenneman D, Gozes I, Moody TW (2001) A vasoactive intestinal peptide antagonist 
inhibits the growth of glioblastoma cells. J Mol Neurosci 17(3):331-339. doi:10.1385/JMN:17:3:331

Sokolowska P, Nowak JZ (2008) Effects of PACAP and VIP on cAMP-generating system and proliferation of C6 glioma cells. J Mol Neurosci 36(1-3):286-291. doi:10.1007/s12031-008-9071-9

Sontheimer H (2003) Malignant gliomas: perverting glutamate and ion homeostasis for selective advantage. Trends Neurosci 26(10):543-549. doi:10.1016/j.tins.2003.08.007

Sontheimer H (2004) Ion channels and amino acid transporters support the growth and invasion of primary brain tumors. Mol Neurobiol 29(1):61-71. doi:10.1385/MN:29:1:61

Sontheimer H (2008a) An unexpected role for ion channels in brain tumor metastasis. Exp Biol Med (Maywood) 233(7):779-791. doi:10.3181/0711-MR-308

Sontheimer H (2008b) A role for glutamate in growth and invasion of primary brain tumors. J Neurochem 105(2):287-295. doi:10.1111/j.1471-4159.2008.05301.x

Straub SV, Nelson MT (2007) Astrocytic calcium signaling: the information currency coupling neuronal activity to the cerebral microcirculation. Trends Cardiovasc Med 17:183-190. doi:10.1016/ j.tcm.2007.05.001

Synowitz M, Ahmann P, Matyash M, Kuhn SA, Hofmann B, Zimmer C, Kirchhoff F, Kiwit JC, Kettenmann H (2001) GABA(A)-receptor expression in glioma cells is triggered by contact with neuronal cells. Eur J Neurosci 14(8):1294-1302. doi:10.1046/j.0953816x.2001.01764.x
Verkhratsky A, Shmigol A (1996) Calcium-induced release in neurons. Cell Calcium 19(1):1-14. doi:10.1016/S0143-4160(96) 90009-3

Verkhratsky A, Orkand RK, Kettenmann H (1998) Glial calcium: homeostasis and signaling function. Physiol Rev 78(1):99-141

Verkhtatsky A, Steinhäuser C (2000) Ion channels in glial cells. Brain Res Brain Res Rev 32:380-412. doi:10.1016/S0165-0173(99) 00093-4

Weaver AK, Bomben VC, Sontheimer H (2006) Expression and function of calcium-activated potassium channels in human glioma cells. Glia 54(3):223-233. doi:10.1002/glia.20364

Weydt P, Möller T, Labrakakis C, Patt S, Kettenmann H (1997) Neuroligand-triggered calcium signalling in cultured human glioma cells. Neurosci Lett 228(2):91-94. doi:10.1016/S0304-3940(97) 00366-2

Wienrich M, Kettenmann H (1989) Activation of substance P receptors leads to membrane potential responses in cultured astrocytes. Glia 2(3):155-160. doi:10.1002/glia.440020304

Yarowsky PJ, Brougher DS, Krueger BK (1994) Glucocorticoid stimulation of sodium channel expression in cultured astrocytes. Ann N Y Acad Sci 746:480-484

Zhu L, Luo Y, Chen T, Chen F, Wang T, Hu Q (2008) Ca2+ oscillation frequency regulates agonist-stimulated gene expression in vascular endothelial cells. J Cell Sci 121:2511-2518. doi:10.1242/ jes.031997 